\title{
'Do not quench the Spirit!' The discourse of the Holy Spirit in earliest Christianity
}

\begin{tabular}{|c|c|}
\hline \multicolumn{2}{|l|}{$\begin{array}{l}\text { Author: } \\
\text { Bert Jan Lieta }\end{array}$} \\
\hline \multicolumn{2}{|c|}{$\begin{array}{l}\text { Affiliations: } \\
{ }^{1} \text { New Testament Studies, } \\
\text { Vrije Universiteit Amsterdam, } \\
\text { The Netherlands }\end{array}$} \\
\hline \multicolumn{2}{|c|}{$\begin{array}{l}{ }^{2} \text { Department of New } \\
\text { Testament Studies, Faculty } \\
\text { of Theology, University of } \\
\text { Pretoria, South Africa }\end{array}$} \\
\hline \multicolumn{2}{|c|}{$\begin{array}{l}{ }^{3} \text { Research Fellow, } \\
\text { Forschungszentrum } \\
\text { Internationale und } \\
\text { Interdisziplinäre Theologie } \\
\text { (FIIT), Universität Heidelberg, } \\
\text { Germany }\end{array}$} \\
\hline \multicolumn{2}{|c|}{$\begin{array}{l}\text { Note: } \\
\text { Prof. Bert Jan Lietaert } \\
\text { Peerbolte a research } \\
\text { associate in the project } \\
\text { 'Biblical Theology and } \\
\text { Hermeneutics', directed by } \\
\text { Prof. Dr Andries G. van Aarde, } \\
\text { professor emeritus and } \\
\text { senior fellow in the Unit for } \\
\text { Advancement of Scholarship } \\
\text { at the Faculty of Theology } \\
\text { of the University of Pretoria, } \\
\text { South Africa. }\end{array}$} \\
\hline \multicolumn{2}{|c|}{$\begin{array}{l}\text { Correspondence to: } \\
\text { Bert Jan Lietaert Peerbolte }\end{array}$} \\
\hline \multicolumn{2}{|c|}{$\begin{array}{l}\text { Email: } \\
\text { l.j.lietaertpeerbolte@vu.nl }\end{array}$} \\
\hline \multicolumn{2}{|c|}{$\begin{array}{l}\text { Postal address: } \\
\text { De Boelelaan 1105, 1081, } \\
\text { Vrije Universiteit, HV } \\
\text { Amsterdam, The Netherlands }\end{array}$} \\
\hline \multicolumn{2}{|l|}{$\begin{array}{l}\text { Dates: } \\
\text { Receivec } \\
\text { Acceptec }\end{array}$} \\
\hline \multicolumn{2}{|l|}{ Read online: } \\
\hline 口ikn & $\begin{array}{l}\text { Scan this QR } \\
\text { code with your } \\
\text { smart phone or } \\
\text { mobile device } \\
\text { to read online. }\end{array}$ \\
\hline
\end{tabular}

The Trinitarian discourse of the 4th and 5th centuries grew out of earlier developments, whilst at the same time reflecting a renewal over against the language of the earliest Christian sources. This article reflects on the way in which early Christianity thought about the Holy Spirit and developed a new discourse on the basis of earlier, Jewish traditions. It situates the development of the idea of the Holy Spirit as God's presence in past and present within the social history of the developing Christian movement, and shows how this idea was connected to the concept of apostolic succession. Thus, emerging Christianity legitimised itself and its social structures by the theology of the Holy Spirit. Its message was presented as old instead of new, as the Holy Spirit had foretold the Christ event. Its organisation was seen as divinely inspired, because its leaders were thought to be endowed with the Spirit. In this development, the narrative of Luke-Acts has thoroughly influenced the way in which Christianity developed a new discourse to present itself as old.

\section{Introduction}

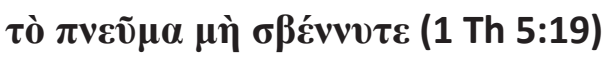

In the late 4th century, Christianity was profoundly divided over the question whether Christ, the Son, should be seen as the first creature the Father had created, as Arius saw it, or was of the same substance of the Father and therefore ungenerated. ${ }^{1}$ This question, known as the Arian controversy, triggered the trinitarian debate that was already slumbering. The question whether God should be seen as One or as Three brought about more than headaches and sleepless nights for many, it became a matter of life and death. The question was eventually answered by emperor Theodosius I (379-395). In the same year he turned Christianity into the state religion of the Roman Empire (380), he issued the edict of Thessalonica, that intended to finally settle the discussion between homoousians and homoiousians. As is well known, the iota was dropped and the homoousians won the debate. To quote from the imperial decree: 'We shall believe in the single Deity of the Father, Son, and the Holy Spirit, under the concept of equal majesty and of the Holy Trinity'. ${ }^{2}$ The emperor not only decided the trinitarian debate in favour of the Niceans, which was a matter of great political importance to him, but he also called for a second ecumenical council, which he convened in Constantinople in 381. At that council the creed of Nicea was adapted, or rather: further refined, and the Holy Spirit was explicitly recognised as one of the three persons of God. ${ }^{3}$ The teaching of the Holy Trinity, and the Holy Spirit as part of that Trinity, became the orthodox, Catholic view of God.

The modern study of the Holy Spirit in early Christianity can take Hermann Gunkel as its point of departure. In 1888, the then 26-year-old Gunkel published his Habilitationsschrift entitled Die Wirkungen des heiligen Geistes nach der populären Anschauung der apostolischen Zeit und die Lehre des Apostels Paulus. ${ }^{4}$ The book, which was initially refused by the faculty of theology in Göttingen because it was considered of poor quality, would eventually change the study of the Holy Spirit in early Christianity profoundly. ${ }^{5}$ Gunkel laid the foundation for a whole new approach to the

\footnotetext{
1.On Arius and his ideas, see Williams (2001:95-116). Williams summarises Arius's position in three statements: "(i) The Son is a creature, that is, a product of God's will; (II) "Son" is therefore a metaphor for the second hypostasis and must be understood in the light of comparable metaphorical usage in Scripture; (III) The Son's status, like his very existence, depends upon God's will' (p. 109; italics original).
}

2.Codex Theodosianus XVI, 1.2 as quoted by Lynch (2010:167), who refers to Pharr (1952:440).

3.Whereas Nicea confessed to believe 'In the Holy Spirit', Constantinople expanded this confession considerably: 'And in the Holy Spirit, the Lord and Giver of Live, who proceeds from the Father, who with the Father and the Son together is worshiped and glorified, who spoke by the prophets.'

4.The English version: Gunkel (1979).

5.See the discussion of Gunkel by Levison (2009). My analysis depends on his.

How to cite this article: Lietaert Peerbolte, B.J., 2015, “"Do not quench the Spirit!” The discourse of the Holy Spirit in earliest Christianity', HTS Teologiese Studies/Theological Studies 71(1), Art. \#3098, 9 pages. http://dx.doi.org/10.4102/hts.v71i1.3098

Copyright: @ 2015. The Authors. Licensee: AOSIS OpenJournals. This work is licensed under the Creative Commons Attribution License. 
subject by focusing on three elements of pneumatology (Levison 2009:xvii-xviii). Firstly, he describes the Wirkungen des heiligen Geistes, instead of studying the Holy Spirit from a systematic perspective. According to Gunkel, the Spirit should not be regarded as a concept or a creed, but as a living reality that the earliest Christians experienced. The Spirit was seen as a source of empowerment, as inspirator, as Divine presence, as a Divine person. The second major change that Gunkel brought about was that he ushered in the so-called religionsgeschichtliche approach. What was so new in 1888 that it initially made Gunkel's Habilitationsschrift unacceptable to established scholars has by now become part and parcel of the methods of biblical scholarship: the idea that the New Testament should be studied as part of a broader corpus of early Christian literature - theologically speaking the canon is the starting point for the Christian tradition, but historically speaking it is an anachronism in the 1st century. Gunkel translated this idea into the insight that the most important context for the study of the New Testament is not the Old Testament, but is formed by the writings of early Judaism. Anyone who intends to reconstruct early Christianity and its beliefs and practices has to take early Judaism into account. ${ }^{6}$ The third major change that Gunkel brought was the fact that he distinguished between Paul and the apostolic church. According to him, Paul was part of the apostolic church, but the two did not coincide. There are continuities and discontinuities to be discerned if one compares Paul to the development of the early church in general.

Almost 130 years of scholarship have passed since Gunkel wrote his landmark Habil. For this article I gratefully use the works of especially James D.G. Dunn (1970), Gordon Fee (1994) and John R. Levison (2009). ${ }^{7}$ Instead of summarising their findings here at the outset, I will focus on the main question that should be addressed here and refer to their works in the footnotes. The present article will explore a few steps in the development of the discourse of the Holy Spirit in the New Testament and the early church. Thus it will discuss the discourse of 'the Holy Spirit' in its Jewish context, Paul's usage of the Spirit, and the Spirit in Luke-Acts. A quick scan of the evidence will point us in the following direction. The New Testament authors describe the Spirit in terms that they knew from their Jewish surroundings. The discourse of the Holy Spirit is an open discourse, in the sense that there is not a uniform, preconceived idea of the Spirit, let alone as part of the Holy Trinity. Instead, the early Christian movement develops its own language on the Holy Spirit and in this language the dynamic aspect is of the utmost importance. The Holy Spirit is seen as the dynamic presence of God in people's lives and in the church communities. The Spirit is also a source of power, of authority, of strength. The final part of this essay will focus on developments in the 2nd century, and finally some general conclusions will be drawn.

6.Gunkel's view of early Judaism was rather negative, and it seems that he was profoundly influenced by the general cultural bias against Judaism that colored much German scholarship of his day.

7.From a systematic point of view, a vital contribution to the study of the Spirit is Michael Welker (1992)
The overall thesis of this essay is the following: the first Christians developed their discourse on the Holy Spirit in direct continuity (and discontinuity) with their surrounding Hellenistic-Jewish context, and used it in order to explain that the new covenant that God had made with Israel, in and through Christ, was thoroughly consistent with the old covenant - the consistent factor being the Holy Spirit. The discourse of the Holy Spirit enabled Christians to explain how God could work through Christ (Christ was inspired or even thought to have been generated by the Spirit), how old Scriptures could have new meaning (the Spirit had spoken through the mouths of the ancients such as Moses and David and now the Spirit is responsible for the correct understanding of what he himself once said), and the church tradition that develops in the early 2nd century is an institutionalisation of the power of the Spirit (through the concept of apostolic succession).

\section{The Spirit in early Judaism}

The abundance of writings passed on to us from early Judaism in the various languages in which they have been transmitted shows a variety of ideas on God's spirit (Levison 2010:1252-1255). The first thing to notice, is that there is no fixed terminology. The preferred combination that the early

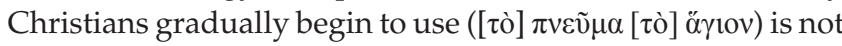
at all widespread in early Jewish sources. Philo and Josephus prefer the combination of $\pi v \varepsilon \tilde{u} \mu \alpha$ and $\theta \varepsilon \tilde{o} o v$, and many other forms of $\pi v \varepsilon \tilde{v} \mu \alpha$ occur. Especially the combination of the noun and a genitive (e.g. the 'spirit of deceit', 'spirit of anger', but also 'spirit of holiness') occurs.

The idea that human beings live in a world of spirits that intend to influence their behaviour (spirits of truth versus spirits of deceit) is attested by a number of the writings from Qumran. The Rule of the Community 3:13-4:26, for example, contains an instruction for new members to make them aware of the fact that they live in a world where the spirits of darkness and deceit consistently try to cause them to stumble, whereas God assists them by his Spirit. Since this instruction grants us direct access to the world in which the early Christians developed their discourse on the Holy Spirit it is worth quoting a phrase from it here:

The Instructor should instruct and teach all the sons of light about the nature of all the sons of man, concerning all the ranks of their spirits, in accordance with their signs, concerning their deeds in their generations, and concerning the visitation of their punishments and the times of their reward. From the God of knowledge stems all there is and all there shall be. [...] He [God] created man to rule the world and placed within him two spirits so that he would walk with them until the moment of his visitation: they are the spirits of truth and of deceit. [...] However, the God of Israel and the angel of his truth assist all the sons of light. He created the spirits of light and of darkness and on them established every deed [...]. (Martínez \&Tigchelaar 1999:77)

The picture is clear: God has planted two spirits in every human being, and these spirits respond to the evil or good spirits in the outside world that they encounter. Other 
passages in the Qumran documents confirm this picture: God's spirit is only one out of many spirits, and even though a 'spirit of holiness' is mentioned, ${ }^{8}$ this is far from the idea of the 'Holy Spirit' as one of the three persons in the Holy Trinity.

The case of the Testaments of the Twelve Patriarchs is exceptionally important to the present topic. This document is a Christian pseudepigraphon in which older, Jewish traditions have been reworked. It shows us not only the rich diversity of views of the 1st centuries of the Christian era, but also indicates that the discourse on the Holy Spirit that led to the establishment of the trinitarian dogma was not the only way in which early Christians spoke about the Spirit of God. The ideas we find here are very similar to what we saw in the Rule of the Community of Qumran: 'Man is portrayed as possessing seven (or eight) spirits (i.e. the senses; TReu 2:2-9); these "are commingled" with seven other "spirits of error"' (TReu 3:3-6) (Kee 1983:778). Joseph is described as 'a good man, one who had within him the spirit of God' (TSim 4:4), but God's spirit is not exactly the only spirit around. Human beings have to shield themselves against the spirit of deceit' (TSim 3:1) and the 'spirits of error' (TSim 6:6). A telling example is found in TLevi 2:3, where Levi describes an insightful moment as follows: 'a spirit of understanding from the Lord came upon me'.

At the same time, there are also texts, especially from Hellenistic Jewish authors, that move into a direction familiar to what happens in early Christianity. A passage in Philo (De Specialibus Legibus I.65) refutes the traditional idea that Jews in general thought that prophecy had ceased from Israel. ${ }^{9}$ Philo explicitly describes what happens when a prophet speaks on behalf of God:

A prophet possessed by God will suddenly appear and give prophetic oracles. Nothing of what he says will be his own, for he that is truly under the control of divine inspiration has no power of apprehension when he speaks but serves as the channel for the insistent words of Another's prompting. For prophets are the interpreters of God, Who makes full use of their organs of speech to set forth what He wills. These and the like are his injunctions as to the conception of the one truly existing God. Having opened with them, he next proceeds to indicate how the honours due to Him should be paid. (Philo, Spec. Laws 1.65, translation Colson [1939])

This passage is all the more interesting if one takes into account that Philo uses the same language of prophetic inspiration for the provenance of the Laws. In case of the Decalogue, he ascribes these commandments explicitly to Moses's inspired status:

For it was in accordance with His [God's] nature that the pronouncements in which the special laws were summed up should be given by Him in His own person, but the particular laws by the mouth of the most perfect of the prophets whom He selected for his merits [Moses] and having filled him with the

8.To mention a few examples: 10: $4: 21 ; 9: 3 ; 1028 \mathrm{~b} 2: 24 ; 402587: 4$

9.Levison (2009:109-221) correctly refutes the wide-spread perception of early Judaism as a period in which prophecy had ceased.

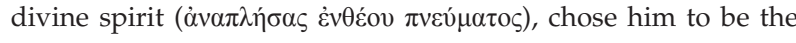
interpreter of His sacred utterances. (Philo, Decal. 175, translation Colson [1939])

We encounter a theme here that will prove important later on in this essay: the idea that God can inspire a prophet through

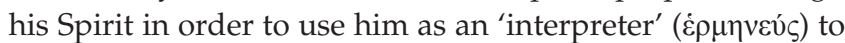
communicate God's will. This idea, on the one hand, takes human agency as its point of departure, whilst on the other hand, it sees inspiration through the Spirit as essential in the process of divine communication. Both themes will prove to play an important role in the early Christian discourse of the Holy Spirit.

One more document to mention here is the Book of Wisdom. In the opening section it describes how 'a holy and disciplined

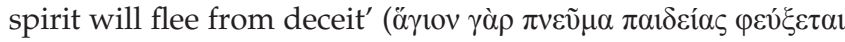
$\delta$ ónov;1:5). Here, the anarthrous use of $\pi v \varepsilon \tilde{u} \mu \alpha$ seems to indicate that the noun refers to a human spirit and not to the divine, but later on in the same document 'Solomon' prays to God and indicates that the Holy Spirit is instrumental in the transmission of wisdom: 'Who has learned your counsel, unless you have given wisdom and sent your Holy Spirit from

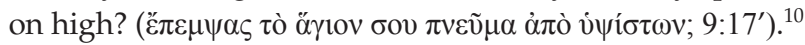

This scanty and all too brief survey of a number of Jewish texts from around the beginning of the Christian era shows us that there was great diversity in the ways in which people spoke and thought about the spiritual world. The world was seen by many as occupied by a large crowd of spiritual beings. The Spirit of God was considered one of many spirits, but the examples we saw do indicate that this Spirit guides people morally, empowers people by communicating divine revelations, and inspires prophets and writings. The Spirit can be seen as the source of wisdom and knowledge, but also as the generator of ecstacy and authority. Though the early Christians do not simply copy the language of their Jewish context, they do take up a number of these themes and use them to interpret, communicate, and legitimate the Christ event. Let us for that reason turn to the earliest Christian author we know, who happened to be so Jewish that he did not even know the term 'Christian': Paul.

\section{The Spirit in Paul}

Dealing with Paul and the Spirit in just a couple of pages is virtually impossible. Gordon Fee needed 915 pages to discuss the most important passages on the Spirit in the corpus paulinum, and there is a good reason for this: the Spirit is the single most important element in Paul's epistles, after Christ, that should be studied in order to understand his ministry and his ideas. The legendary New Testament scholar F.F. Bruce (1977) had a good reason to choose the title of his monograph on Paul: Paul - Apostle of the Free Spirit. ${ }^{11}$

\section{Unless otherwise indicated, translations are taken from the NRSV.}

11.The book opens with the magisterial dedication: 'To my grand-daughters Helen Anna, Esther and Winona Mary. And to my grandsons Peter, Frederick, Alan and Paul. Bearing in mind T.R. Glover's comment on a Roman Emperor's condemnation of the Apostle to the Gentiles - that the day was to come when men would call of the Apostle to the Gentiles - that
their dogs Nero and their sons PAUL'. 
The Spirit is crucial to Paul's thought and ministry. In fact, it is worth emphasising again that for Paul the Spirit was far more than a concept - it was the term by which he described the experiential dimension of his theology, a lived reality instead of an abstract concept. ${ }^{12}$

In his opus magnum, Fee gives a detailed exegesis of every single passage in the corpus paulinum that possibly refers to the Spirit. For this moment, it may suffice to summarise his findings in short. According to Fee (1994:803-826), the first dimension about the Spirit in Paul is eschatological in character. The Spirit is the fulfilment of the eschatological promise that God would speak directly to his people, through the Spirit, in the final days of history. Paul uses three main metaphors to explain the function of the Spirit: the Spirit is a down payment, firstfruits, and seal of God. The first two metaphors indicate that the presence of the Spirit is, on the one hand, a fulfilment of an old promise, but on the other hand, points to the future in which the remainder of the promise shall be fulfilled. The 'seal' metaphor refers to ownership: 'we' are sealed with the Spirit, and this means that God has indicated that we belong to him. Since the Torah was inspired by the Spirit, a spiritual reading of Torah after the Christ event actually reveals the true nature of Torah.

The second role of the Spirit in Paul is to establish God's personal presence (Fee 1994:827-845). It is as though in early Judaism people had come to regard God as so transcendent in character, that only the dynamic presence in the form of the Spirit was acceptable to Paul and many of his contemporaries. The Holy Spirit figures as a person in Paul, and this person equals God. ${ }^{13}$ The third concluding chapter in Fee's monograph describes the Spirit in its soteriological function: the Spirit saves (Fee 1994:846-895). One of the saving functions of the Spirit is the role the Spirit plays in the process of revelation. Here, Fee's Paul closely approaches the ideas of Philo on prophecy and inspiration: the mystery of history has been concealed from the human eye for centuries, but now, in Paul's day, the Spirit has revealed that Christ has always been intended in the history of Israel. It is the Spirit who leads to conversion, and a life in the Spirit eventually consists of a life of sanctification. This life, naturally, is not an individual life, but a community life. The Spirit is present within the community and the best proof of this is the presence of prophecy and glossolalia in the congregations. ${ }^{14}$

12.For the argument that Paul's ideas should be read from the perspective of his experiential context, see Lietaert Peerbolte (2008:159-176). Paul's predisposition for ecstatic experiences is analysed by Shantz (2009).

13.In his commentary on Isaiah 40.9 , Jerome says of the Holy Spirit that it proves that God has no gender (in divinitate enim nullus est sexus), because in Greek the Spirit is referred to as a neuter ( $\tau \dot{\alpha} \pi v \varepsilon \tilde{u} \mu \alpha)$, in Hebrew the Spirit is mostly feminine (חור) and in Latin the Spirit is male (spiritus). Interestingly enough, Jerome makes this remark as comment on the fact that Jesus calls the Holy Spirit his 'mother' in the Gospel according to the Hebrews. This feminine understanding of the Holy Spirit is preserved in early Syriac literature; see Brock (1990:73-88).

14.Even though I consider Fee's book a more than excellent study, I part ways with him when he speaks of the 'Trinitarian presuppositions' to Paul's theology and his 'Trinitarian understanding 'Tr God' (e. 1994:898). The concept of the Trinity is a 'Trinitarian understanding of God" (e.g. 19gh:898). The concept of the Trinity is a later, patristic concept, and although Father, Son, and Holy Spirit are of the utmost importance to Paul, the usage of this terminology obfuscates rather than clarifies what is happening in Paul.
There are several passages where Paul unequivocally speaks of the importance of the Spirit and it will not be possible to deal with all of them in any degree of detail here. The few passages that must be referred to here are the passages in which Paul speaks of the Spirit in relation to the Mosaic Law, passages where Paul mentions the Spirit as indication of God's direct presence within the congregation, and the signs of an apostle Paul mentions as evidence that he was actually inspired himself and thus should indeed hold authority.

\section{Spirit and Law}

In two famous passages in his letters Paul deals with the relation of the Spirit and the Mosaic Law: Galatians 4:12-5: 26 and Romans 8. A few brief observations have to suffice. First of all, it is evident that for Paul the Spirit is granted to the believers because of and through Christ. Paul carefully crafts his argument: the Spirit stood at the origin of the Law (Rm 7:14), but now, in Christ, the Spirit brings a new Law: 'For the law of the Spirit of life in Christ Jesus has set you free from the law of $\sin$ and of death' (Rm 8:2). Thus, the Spirit brings a solution to a theological problem Paul has to face: how should the Christ movement interpret the Law? In concreto, Paul is dealing with the reality that God has opened up Israel to the Gentiles and now it is Christ, and no longer the Law, that determines whether or not someone belongs to Israel. If this is the case, did God change his mind and abolish the Law now that the Messiah has come? Paul solves the problem of renewal in God (did the Almighty change his mind?!) by means of the Spirit: it was the Spirit who had brought the Law, it is the Spirit through whom the Law should be interpreted now, and the community of believers in Christ centres on the Spirit. In fact, the Spirit even enables Paul to make the argument that the Law should be read spiritually, as he takes up the prophetic motif of 'circumcision of the heart': 'Rather, a person is a Jew who is one inwardly, and real circumcision is a matter of the heart-it is spiritual and not literal' ( $\varepsilon \varepsilon \rho ı$ iт

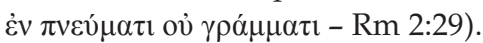

\section{Presence in the congregation}

It is clear that Pauline congregations were charismatic communities in the sense that the presence of God was felt directly and interpreted as the influence of the Spirit. In 1 Corinthians Paul admonishes the congregation of believers in Corinth. In chapter 12 he explicitly deals with the variety of $\chi \alpha \rho i ́ \sigma \mu \alpha \tau \alpha$ in the congregation and there he uses the metaphor of the 'body of Christ' $(12: 12,27)$. In the often overlooked opening statement to his argument, Paul introduces his view succinctly:

Therefore I want you to understand that no one speaking by the Spirit of God ever says 'Let Jesus be cursed!' and no one can

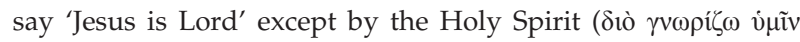

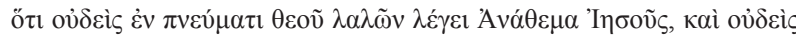

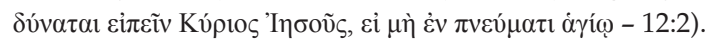

The crucial expression here is $\dot{\varepsilon} v \pi v \varepsilon v ́ \mu \alpha \tau \imath \theta \varepsilon o \tilde{v} \lambda \alpha \lambda \tilde{\omega} v$ : these words clearly indicate that for Paul the confession of Jesus as 
Lord was not a human effort, but inspired speech by the Holy Spirit. As a result, we have to say that $\pi i \sigma \tau \iota \varsigma$ is not just a human response to the Christ event, but a gracious gift of the Spirit. For Paul, the Spirit is thus present in every believer. Life as a believer is therefore a vibrant state of existence in which the human being is taken up in the community of Christ through the Spirit. The community of believers is therefore a Spirited community and God himself is present in its life. Not just in its worship, but in all activities of the community. This is the reason why, especially in 1 Corinthians, Paul puts so much emphasis on sanctification and ethics. To put it bluntly: 1 Corinthians indicates that, according to Paul, the Spirit is even present when people are having sex, and for this reason there is no single area of life that should not be sanctified by the correct halakha.

\section{Spirit and power}

Traditionally, the Spirit is seen as a source of power and authority. This clearly comes to the fore in the gospel narratives about Jesus, but also in Paul this theme is present. In the many debates about Paul's apostolic authority, Paul could explicitly refer to the fact that he had performed the 'signs of an apostle' within the Corinthian congregation (2 Cor 12:12). These 'signs' are further explained as 'signs,

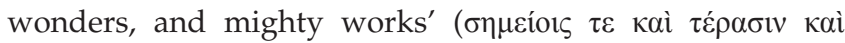

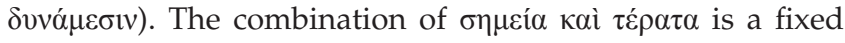
expression stemming from the Exodus tradition and referring to the liberating presence of God as shown in wondrous deeds. ${ }^{15}$ To this fixed combination, Paul adds the word $\delta v v \alpha$ q $\varepsilon 1 \zeta$, which is closely connected to the Spirit. The signs of the apostle Paul here refers to, whatever their character may have been, are thus an expression of the fact that an apostle was apparently seen as especially gifted with the Spirit. An apostle was therefore a charismatic preacher and miracle worker. This observation is confirmed by Paul's words in Romans 15:18-19. Here, Paul looks back at his ministry so far and characterises it as follows:

For I will not venture to speak of anything except what Christ has accomplished through me to win obedience from the Gentiles, by word and deed, by the power of signs and wonders, by the power of the Spirit (of God), so that from Jerusalem and as far around as Illyricum I have fully proclaimed the good news of Christ.

His ministry did not just consist of preaching ('word') but also of actions ('deed'). To characterise his actions Paul uses the exact same combination of words as in 2 Corinthians

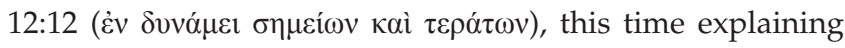
that 'power of signs and wonders' as the 'power of the Spirit [of God] ${ }^{\prime}{ }^{16}$ It is clear that Paul thought of himself as inspired by the Holy Spirit, not just in his preaching, but even more so in his deeds.

15.According to Meeks (1967:162-165), the performing of 'signs and wonders' ultimately goes back to the Exodus traditions on Moses. Based on these traditions, the expectation grew that a new 'prophet like Moses' would also support his actions by 'signs and wonders', thereby proving his divine commissioning.

16.The genitive $\theta \varepsilon \circ \tilde{v}$ is absent in codex Vaticanus, and a large number of manuscripts

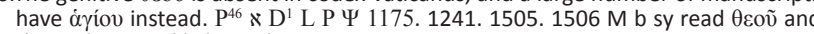
this is the most likely reading.

\section{Summary}

For Paul the Spirit is of the utmost importance. The Spirit warrants the continuity with the past, since it is by the Spirit that God has spoken and still speaks through the Law and the Prophets. The Spirit is quintessential for the existence of the communities of believers and the Spirit pervades the lives of the believers, both individually and collectively. Inspiration by the Spirit leads to the performance of the gospel in word and deed, and as an apostle Paul claimed to have an especially privileged position thanks to the Spirit.

\section{The Spirit in Luke-Acts}

The letters of Paul may be the oldest documents that we can retrospectively label as 'Christian', but the history of Christianity of course begins with the ministry of Jesus. Given the fact that the reception of that ministry in the early Church was highly influenced by the characteristics described in Luke-Acts, for the present purpose we must turn our attention to the way in which these two works depict first the ministry of Jesus and then the growth of the Church as the result of the Spirit's presence.

The Gospel of Luke and the Book of Acts both ascribe the cause of the major events in their narratives to the Spirit. When the angel Gabriel announces the birth of John the Baptist to Zechariah, it is the Spirit who is introduced as the decisive factor: 'even before his birth he [John] will be filled with the Holy Spirit'. ${ }^{17}$ When the same Gabriel announces the birth of Jesus to Mary, he again refers to the Holy Spirit, but here the Spirit does not just fill Jesus, he actually begets him:

The Holy Spirit will come upon you, and the power of the Most High will overshadow you; therefore the child to be born will be holy; he will be called Son of God. (1:35)

It is thus the Holy Spirit who puts John and Jesus where they should be, and from here onward the story can begin.

After the story of Jesus' birth is narrated, Luke continues with the dedication of Jesus in the temple (2:22-29). Jesus and his parents are met by the old Simeon, who is introduced as 'righteous and devout, and the Holy Spirit rested on him' (2:25). The Spirit had revealed to Simeon that he would see the Messiah, and now the Spirit had guided the old man into the temple. There he takes Jesus in his arms and praises God. The narrative function of this episode is important: first the Spirit has caused Mary's pregnancy, and now the same Spirit speaks through Simeon and confirms the identity of the child Jesus. ${ }^{18}$

In 3:1-22, Luke describes the actions of John the Baptist, a description that results in the baptism of Jesus by John. As in Mark, Luke's source for this account, Jesus' baptism ends with the Holy Spirit descending on him in the form of a dove,

17.Luke-Acts is consistent in its use of the term $\pi v \varepsilon \tilde{v} \mu \alpha$ ö $\gamma 10 v$, either anarthrous or with the article.

18.The prophetess Anna repeats the confirmation of Jesus' identity in 2:36-38. 
and a voice from heaven addressing Jesus as 'my Son'. It is important to see that Luke here changes the account over against the version of Mark. In Mark, it is Jesus who sees that the heavens are being torn apart, and the descent of the Spirit thus becomes a visionary experience by Jesus. Here in Luke, the event is clearly visible for all present. Thus, Jesus' baptism functions as the narrative confirmation of the fact that he is empowered by the Spirit.

This sets the stage for the action to begin. First the Spirit guides Jesus into the desert, where the Devil tries to beguile him. After Jesus has resisted the Devil's temptations, he returns to Galilee, 'filled with the power of the Spirit' (4:14). He there begins his public ministry in the synagogue of Nazareth. The passage that Jesus reads to the synagogue is Isaiah 61:1:

The Spirit of the Lord is upon me, because he has anointed me to bring good news to the poor. He has sent me to proclaim release to the captives and recovery of sight to the blind, to let the oppressed go free, to proclaim the year of the Lord's favor.

Jesus hands back the scroll, sits down, and just says: 'Today this scripture has been fulfilled in your hearing'. A clearer narrative introduction to the ministry of Jesus as guided by the Holy Spirit is impossible. For Luke Jesus so much represents God that the only way he can narrate the story of his ministry is by assigning Jesus' power and even his provenance to the Holy Spirit.

Interestingly enough, the Holy Spirit hardly features in the rest of the gospel of Luke, but returns full force in the opening section of the Book of Acts. Here, too, the Spirit functions as the originator of the action. It is the Spirit who guides the apostles, they receive and transmit the Spirit, and it is the Spirit who eventually communicates God's decision to open up the Christ movement to the Gentiles. Then after a consensus is reached at the apostolic council in Jerusalem, the decision made by the apostles is communicated as a decision by the Holy Spirit: 'it has seemed good to the Holy Spirit and to us to impose on you no further burden than these essentials [...]' (Ac 15:28). Various elements of the account of Acts are worthy of our attention, but for now two elements of the story should be mentioned in particular: the introduction in Luke-Acts of the idea of a confined group of twelve apostles who were divinely inspired by the Spirit, and the notion that they hand on the Spirit by means of the laying on of hands.

\section{The Apostles in Luke-Acts}

In his description of the resurrection appearances in 1 Corinthians 15:3-8 Paul explicitly distinguishes between 'the Twelve' and 'all the apostles':

For I handed on to you as of first importance what I in turn had received: that Christ died for our sins in accordance with the scriptures, and that he was buried, and that he was raised on the third day in accordance with the scriptures, and that he appeared to Cephas, then to the twelve. Then he appeared to more than five hundred brothers and sisters at one time, most of whom are still alive, though some have died. Then he appeared to James, then to all the apostles. Last of all, as to one untimely born, he appeared also to me.

In Paul's letters the concept of apostleship appears rather fluid: not just he himself claims apostolic authority, but he does so also for Barnabas (1 Cor 9:6), and even for Andronicus and Junia (Rm 16:7). All in all it is clear that in Paul's day the title 'apostle' was not restricted to the twelve disciples who had been Jesus' closest followers (Lietaert Peerbolte 2003:177-190).

In the gospel of Luke the term 'apostle' is applied to the twelve disciples of Jesus upon their return from their mission to preach on Jesus' behalf. Jesus sends them out by

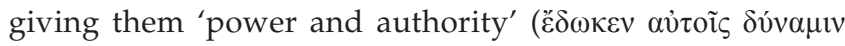

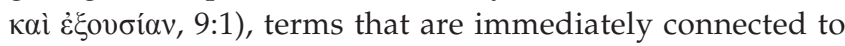
the discourse of the Holy Spirit, and has them proclaim the gospel, cast out demons, and heal the sick. When they return, Luke all of a sudden refers to them by the term 'apostles', meaning of course 'envoys': 'On their return the

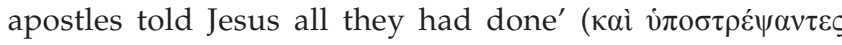

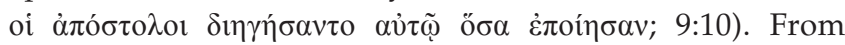
this point onward, Luke restricts the term 'apostle' to the twelve disciples. In the opening lines of the Book of Acts, Jesus' teaching is referred to as 'giving instructions through the Holy Spirit to the apostles whom he had

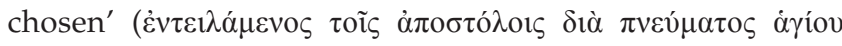
ov́ $\dot{\varepsilon} \xi \xi \lambda \dot{\varepsilon} \xi \alpha \tau o)$. Jesus' commissioning of the apostles and the instructions he gave them are thus both related to the Holy Spirit, and this puts the twelve apostles in a position of authority. This position of authority is subsequently strengthened and confirmed at the events of Pentecost (Ac 2:1-13). There, the apostles receive the Holy Spirit and from that moment onward they are described as people in a position of authority. It is up to them to hand on the Spirit by the laying on of hands (cf. Ac 8:14-17). ${ }^{19}$

\section{'It has seemed good to the Holy Spirit and to us' (Ac 15:28)}

After the apostles have received the Holy Spirit at Pentecost, Peter preaches a sermon to those present in the temple. There, he indicates that he speaks through the power of the Holy Spirit and that the Holy Spirit had announced the events that had taken place in Jesus' life. The sermon first interprets the events taking place in the temple as the fulfilment of the prophecy of Joel concerning the eschatological outpouring of the Spirit. Peter's sermon ends with the call for obedience to all present and the invitation to be baptised 'in the name of Jesus', and subsequently 'receive the gift of the Holy Spirit' (Ac 2:38).

As the rest of the story is told, the Spirit proves to be the decisive factor in many events. After Peter's vision in chapter 10, the 'circumcized believers were astounded that the gift of the Holy Spirit had been poured out even on Gentiles'

19. For a discussion of how baptism and Spirit related in Acts 8, see Dunn (1970:5572). It is evident that Luke's account intended to convey the message that only the apostles have the authority to confer the Spirit. 
(Ac 10:45). The Gentile mission is thus introduced and legitimated by the Holy Spirit.

When eventually the apostles convene in Jerusalem, together with Paul and Barnabas, to settle the dispute over the Mosaic Law, they introduce their apostolic decree as a decision by the Holy Spirit and them:

For it has seemed good to the Holy Spirit and to us to impose on you no further burden than these essentials: that you abstain from what has been sacrificed to idols and from blood and from what is strangled and from fornication. If you keep yourselves from these, you will do well. Farewell. (Ac 15:28-29)

As will be argued in the final part of this article, this would prove to be a successful idea: the gathering of church officials who unanimously settled a theological debate would later be seen as proof of the presence of the Holy Spirit.

\section{Summary: Luke-Acts}

In Luke-Acts the Holy Spirit plays a crucial role in the entire narrative structure. The Spirit stands at the origin of John the Baptist and even generates Jesus' birth. The Spirit empowers Jesus to perform his ministry, and after the resurrection the Spirit empowers the twelve apostles to perform signs and wonders. It is the Spirit who guides the apostles in their actions, and it is the Spirit who opens up the Christ movement to the Gentiles. Thus, in Luke-Acts the Spirit is actually the most important force behind Jesus' ministry and behind the ministry of his successors, the apostles.

\section{So far: The Holy Spirit as dynamic empowerment}

The evidence surveyed thus far enables us to draw a few preliminary conclusions. In the first place, it is evident that the Christian discourse of the Holy Spirit developed out of existing Jewish traditions. It refers to texts and traditions in the Jewish Bible, the Old Testament, but it should also be understood within the context of Hellenistic-Jewish speculations on the presence of God in a world filled with spirits. At the same time, this contextualisation indicates that the Holy Spirit is certainly not just a figure of speech.

A second conclusion to be drawn here, is that the orthodox view of God as the Holy Trinity consisting of the Father, the Son, and the Holy Spirit, developed out of a discourse that is found in the apostolic writings the collection of which became known, in the same period in which the concept of the Holy Trinity was formulated in its authoritative form, as the 'New Testament'. Important elements in the discourse of the Holy Spirit are the concepts of empowerment, the dynamic presence of God, and the authority granted to people by the Holy Spirit. Jesus' ministry is depicted, especially - though not exclusively - in Luke-Acts, as evoked by the Spirit.

A third conclusion that is warranted on the basis of the material discussed so far, is that we can discern a development of institutionalisation in Luke-Acts over against the situation depicted in the letters of Paul. Apparently the emerging Christian movement felt the need to organise itself and its history around the principle of the handing on of the Holy Spirit. Perhaps even in reply to the charismatic chaos of the Corinthian congregation Luke-Acts intends to organise the Christian movement according to the principle of Spirit endowment: it was God who, through the Spirit, chose Jesus, Jesus who, again through the Spirit, chose the Twelve Apostles, and these Twelve Apostles who, again through the Spirit, accepted the ministry of Paul and opened up the Christian movement to the Gentiles. The fact that Luke-Acts organises the history of the Christian movement around the Holy Spirit as its main protagonist would have enormous consequences, as the final part of this article will show.

\section{Developments in the 2 nd century}

The 2nd century is an often overlooked, but massively important period for the development of Christianity and its beliefs and practices. A number of authors speak about the Holy Spirit in ways that are clearly indebted to some of the ideas that we encountered in Paul and Luke-Acts, and that can be seen as steps in the direction of the fully developed Trinitarian theology of the 4 th century. The three elements in the discourse on the Holy Spirit that are especially worth mentioning are the Spirit as God's empowering presence in a line of apostolic succession, the Spirit as the inspiration of the Holy Scriptures, and the Spirit in relation to the Father and the Son.

A writing that was probably written in the last decade of the 1st century, and is usually reckoned amongst the so-called 'Apostolic Fathers', is the letter known as 1 Clement. ${ }^{20}$ In this letter bishop Clement of Rome, who is unmentioned in the document itself but identified already at an early stage as the author of the letter, addresses the Christian congregation of Corinth. Clement claims apostolic authority for himself and sees the Holy Spirit as speaking through him. He can refer to the prophets of Israel as 'those who administered the gracious gift of God'

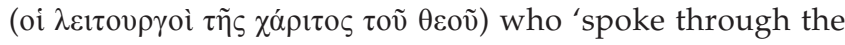
Holy Spirit about repentance' (8:1; see also 13:1; 16:2; 45:2). In 63:2, Clement explicitly refers to his own writing as inspired by the Holy Spirit:

For you will make us joyful and happy if you become obedient to

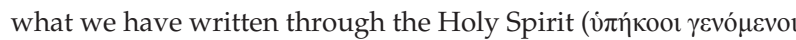

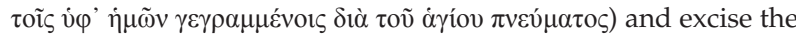
wanton anger expressed through your jealousy, in accordance with the request we have made in this letter for your peace and harmony.

It is clear that Clement sees himself as standing in the tradition of the apostles, and it is not by accident that Clement is the first Christian author to describe the principle of apostolic succession. In 42:1-44:6, too lengthy

20.Passages from the Apostolic Fathers are quoted from Ehrman (2003). 
a passage to quote in its entirety, Clement describes how God sent Jesus and Jesus sent the apostles: 'they went forth proclaiming the good news that the Kingdom of God was about to come, brimming with confidence through

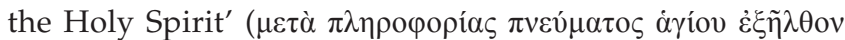

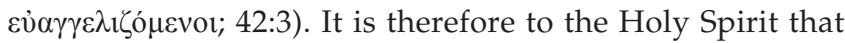
Clement ascribes the history of God's communication with humankind, because not only Jesus and the apostles were inspired by the Spirit, but also the ancient scriptures are, as is Clement himself! In 45:2 Clement describes how the Corinthians have read their Bible: 'You have gazed into the holy and true Scriptures that were given through the Holy

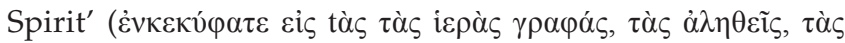

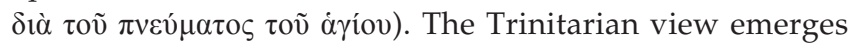
in Clement's language, as he instructs the Corinthians: 'For God the Father is alive, and the Lord Jesus is alive, and the

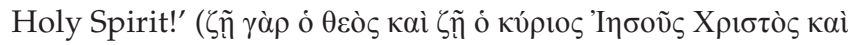

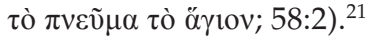

The rise of the Trinitarian discourse can also be seen in the early church manual known as the Didache. For the practice of baptism, the Didache gives a simple instruction: 'Having said all these things in advance, baptize in the name of the Father and of the Son and of the Holy Spirit, in running

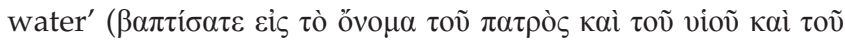

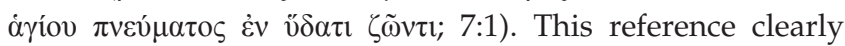
indicates the usage of Trinitarian language in the ritual context of baptism, which is of course already present in the missionary command with which the gospel of Matthew closes (Mt 28:19-20).

The letters of Ignatius, probably written in the first decade of the 2 nd century, ${ }^{22}$ reflect the same development. Here, too, the Holy Spirit is mentioned on the one hand as inspirator and God's empowering presence, and on the other hand as the ultimate originator of the prophecies of the Jewish Bible. Ignatius refers to Jesus' birth as generated by the Holy Spirit (Eph. 18), and even calls Jesus 'God' (Smyrn. 1). The battle between right and wrong is a battle between Simon Magus and the Holy Spirit (Phil. 6:1).

In Justin Martyr's perception, the Old Testament is a collection of divinely inspired writings that predict the Christ event, and it is the Holy Spirit who filled their authors at the time they wrote and made them predict the advent of Christ. ${ }^{23}$ This comes especially to the fore in the Dialogue with Trypho, in which Justin debates the interpretation of the Old Testament with Trypho. According to Justin, it was the Holy Spirit who spoke through the writings of the prophets. In his

21.Although Clement clearly uses this Trinitarian language, he can also refer to God as

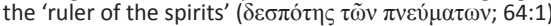

22.Ehrman (2003:205, vol. 1): 'Eusebius indicates that it occurred midway through the reign of Trajan (98-117 CE; Eccl.Hist. 3.36).

23.For a detailed analysis of Justin's ideas on the Holy Spirit, see Briggman (2012:931), who especially focuses on the interplay of Spirit theology and christology in 1 , who especially focuses on 1 Apol. 33 and Dial. $87-88$ and concludes that although Justin does use the late Trinitarian discourse, his theology of the Holy Spirit is not yet as fully developed as it would be in the 4th century. Briggman (2012:31): 'we cannot [...] condemn a theologian of the second century for failing to meet the standards of the fourth century'. first apology, Justin ascribes the Books of Moses to the Holy Spirit:

And the Holy Spirit of prophecy taught us this, telling us by Moses that God spoke thus to the man first created: 'Behold, before thy face are good and evil: choose the good'. (Justin, 1 Apol. 44) $)^{24}$

Justin frequently mentions the '(Holy) Spirit of prophecy' as the originator of the books of the Old Testament and in the conversation with Trypho he stresses that the Holy Spirit generates knowledge of God: 'Will the mind of man see God at any time, if it is uninstructed by the Holy Spirit?' (Justin, Dial. 4). The prophets of old have spoken through the Holy Spirit (cf. Dial. 7, 25, 32), and the perception of what they wrote by the reader is made possible through that same Holy Spirit.

Later authors in the 2nd century develop a more elaborate theology of the Holy Spirit. Thus, Tatian, a student and successor of Justin, speaks about the necessity for human beings to unite with the Holy Spirit. In his anthropology Tatian is convinced that God had given life to human beings by giving them his breath (Spirit; Gn 2:6):

But further, it becomes us now to seek for what we once had, but have lost, to unite the soul with the Holy Spirit, and to strive after union with God. ${ }^{25}$

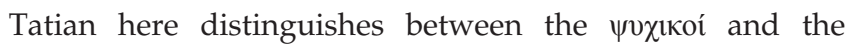
$\pi v \varepsilon v \mu \alpha \tau i \kappa o i$, in the sense that the first category consists of people who are not filled with the Holy Spirit whereas people in the second category are. According to Tatian, the endowment of the Spirit even helps people to see the demons

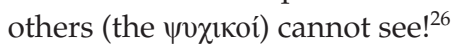

In his Apology, chapter 10, Athenagoras explicitly describes the Holy Spirit as part of God. He refutes the allegation that Christians are atheists and describes God as the triune ruler of the spiritual world:

The prophetic Spirit also agrees with our statements. 'The Lord,' it says, 'made me, the beginning of His ways to His works.' The Holy Spirit Himself also, which operates in the prophets, we assert to be an effluence of God, flowing from Him, and returning back again like a beam of the sun. Who, then, would not be astonished to hear men who speak of God the Father, and of God the Son, and of the Holy Spirit, and who declare both their power in union and their distinction in order, called atheists? Nor is our teaching in what relates to the divine nature confined to these points; but we recognize also a multitude of angels and ministers, whom God the Maker and Framer of the world distributed and appointed to their several posts by His Logos, to occupy themselves about the elements, and the heavens, and the world, and the things in it, and the goodly ordering of them all. ${ }^{27}$

\footnotetext{
24.Translation Ante Nicene Fathers.

25.Tatian, Exhortation to the Greeks, 15; translation Ante Nicene Fathers.

26.Tatian, Exhortation 15,7. Trelenberg (2012), 127, note 178, refers to Tertullian who argues a similar idea in De anima 8,5 .
}

27.Translation Ante Nicene Fathers. 
It would be enticing to also look into the writings of Irenaeus and Tertullian, ${ }^{28}$ but for the present purpose the above survey will have to suffice. It is clear, from the evidence presented, that the discourse of the Holy Spirit further develops in the 2nd century into a direction what would eventually shape the creed of the Holy Trinity as formulated in the Constantinople revision of Nicea.

\section{Conclusion}

Given the broad scope of this contribution, its conclusions can only be tentative in character, but the following points should at least be mentioned. The discourse of the Holy Spirit as part of the Holy Trinity develops in the first four Christian centuries from an open and diffuse discourse in the 1st century into the formulation reached in the Constantinople revision of the Nicean creed. This discourse is firmly rooted in Jewish soil and speaks of the Holy Spirit as God's immanent presence in Israel, in the Scriptures, and in the Christian communities and even in individual believers. The possible reproach that Christianity was a new movement was countered by the interpretation of the Scriptures of Israel as inspired by the Spirit and pointing at Jesus Christ. The Spirit had spoken in the past and the Spirit was seen as providing the Christians with the correct understanding of what he himself had once said. But not only was the Spirit thus used to claim authority for the Jewish Scriptures and their Christian interpretation, the Spirit also legitimised church structures. The concept of Luke-Acts in which twelve apostles continue the ministry of Jesus influenced the growth of the church through the principle of apostolic succession. This principle in itself was foundational for the idea that church councils were divinely inspired, by the Holy Spirit, and that their decisions were thus acts of divine revelation through the Spirit. The developments of the 1st centuries can also be characterised as an attempt to canalise the activity of the Spirit and to use the authority of the Spirit to legitimise power structures that slowly developed through the offices of especially bishops and priests. It is clear that the Spirit will never be restricted by human offices, and thus mystics and charismatics have challenged the structures of the catholic church straight from the beginning. This, however, is a different subject.

28.On Irenaeus see especially Briggman (2012:32-305). Briggman (2012:206-215) discusses Origen, Tertullian, and Novatian.

\section{Acknowledgements Competing interests}

The author declares that he has no financial or personal relationships which may have inappropriately influenced him in writing this article.

\section{References}

Briggman, A., 2012, Irenaeus of Lyons and the theology of the Holy Spirit, Oxford University Press, Oxford.

Brock, S., 1990, 'The Holy Spirit as feminine in early Syriac literature', in J. Martin Soskice (ed.), After Eve. Women, theology, and the Christian tradition, pp. 73-88, Marshall Pickering, London.

Bruce, F.F., 1977, Paul. Apostle of the free spirit, Paternoster, Exeter.

Colson, F.H., 1939, Philo, vol. 8, Loeb Classical Library, Harvard University Press, Cambridge.

Dunn, J.D.G., 1970, Baptism in the Holy Spirit. A re-examination of the New Testament teaching on the gift of the Spirit in relation to Pentecostalism today, Westminster, Philadelphia, PA.

Ehrman, B.D., 2003, The Apostolic Fathers, vols. 2, Loeb Classical Library, Harvard University Press, Cambridge.

Fee, G., 1994, God's empowering presence. The Holy Spirit in the letters of Paul, Hendrickson, Peabody, MA.

Gunkel, H., 1979, The influence of the Holy Spirit. The popular view of the Apostolic Age and the teaching of the Apostle Paul, transl. R.A. Harrisville \& P.A. Quanbeck II, Fortress, Philadelphia, PA.

Kee, H.I., 1983, 'The Testaments of the Twelve Patriarchs', in J.H. Charlesworth (ed.), Old Testament Pseudepigrapha-Apocalyptic literature and testaments, vol. 1, pp. 775-828, Doubleday, Garden City, IL.

Levison, J.R., 2009, Filled with the Spirit, William B. Eerdmans Publishing Company, Grand Rapids, MI.

Levison, J.R., 2010, 'Spirit, Holy', in D.C. Harlow \& J.J. Collins (eds.), The Eerdmans dictionary of early Judaism, pp. 1252-1255, William B. Eerdmans Publishing Company, Grand Rapids., M

Lietaert Peerbolte, L.J., 2003, Paul the missionary, Peeters, Leuven. (Contributions to biblical exegesis and theology vol. 34).

Lietaert Peerbolte, L.J., 2008, 'Paul's rapture: 2 Corinthians 12:2-4 and the language of the mystics', in F. Flannery, C. Shantz \& R.A. Werline (eds.), Experientia-Inquiry into religious experience in early Judaism and Christianity, vol. 1, pp. 159-176, $\mathrm{SBL}$, Atlanta, GA.

Lynch, J.H., 2010, Early Christianity. A brief history, Oxford University Press, New York, NY.

Martínez, F.G. \& Tigchelaar, E.J.C., 1999, The Dead Sea Scrolls study edition, Brill, Leiden.

Meeks, W.A., 1967, The prophet-king. Moses traditions and the Johannine Christology, E.J. Brill, Leiden. (Supplements to Novum Testamentum 14.)

Pharr, C. (transl.), 1952, The Theodosian Code and Novels and Sirmondian Constitutions, Princeton University Press, Princeton, NJ.

Roberts, A. \& Donaldson, J., 1885, The Ante-Nicene Fathers: The writings of the Fathers down to A.D. 325, Ante-Nicene Christian library, T. \& T. Clark, Edinburgh.

Shantz, C., 2009, Paul in ecstasy. The neurobiology of the Apostle's life and thought, Cambridge University Press, Cambridge.

Trelenberg, J., 2012, Tatianos. Oratio ad Graecos Rede an die Griechen, Mohr Siebeck, Tübingen. (Beiträge zur historischen Theologie 165).

Welker, M., 1992, Gottes Geist. Theologie des Heiligen Geistes, Neukirchener, Neukirchen-Vluyn.

Williams, R., 2001, Arius. Heresy and tradition, 2nd edn., SCM, London. 